\section{Future brightens for Eddington project to hunt distant planets}

Laura Nelson, London

On the same day that Venus was observed as a black disk traversing the Sun, the European Space Agency (ESA) was advised to resurrect a mission based around such mini-eclipses. If built, the Eddington space-based observatory will use similar events to search for planets in other solar systems.

The $€ 210$-million (US\$250-million) project would consist of three telescopes arranged to track the light intensities of many stars over several years. The plan is to place the structure beyond the Moon to allow uninterrupted observation of thousands of stars.

When, as viewed from Earth, Venus crossed the path of the Sun on 8 June, the silhouette of the planet reduced the star's brightness by a tenth of a per cent. Eddington is designed to detect changes a thousand times smaller than that, and will use dips in star brightness to deduce the existence of distant planets.

Eddington will also investigate what the insides of stars are made of, by measuring the frequency of emitted light and deducing information about their chemical and physical properties. This may illuminate star evolution: "Studying younger and older stars will help us understand the Sun," says Ian Roxburgh, an astronomer at Queen Mary, University of London, and a coordinator in the mission's design team.

The project was approved in 2002 for launch in 2008 , but was shelved last November after its design phase, because the ESA budget would not stretch to cover its cost.

On 8 June, ESA's Space Science Advisory Committee (SSAC) recommended that the project be given precedence after receiving advice from several other committees. "The SSAC strongly endorsed Eddington," says Giovanni Bignami, who is chairman of the committee and director of the CESR, the laboratory of space astrophysics in Toulouse, France. "It is our first priority."

Eddington now tops the space agency's list of unfunded science missions. "If ESA receives more money, Eddington would be the priority," says Roxburgh.

Jean-Jacques Dordain, directorgeneral of ESA, is currently seeking an extra $€ 700$ million in funding for the agency from its member states.

Eddington should be built if a fraction of that comes through.

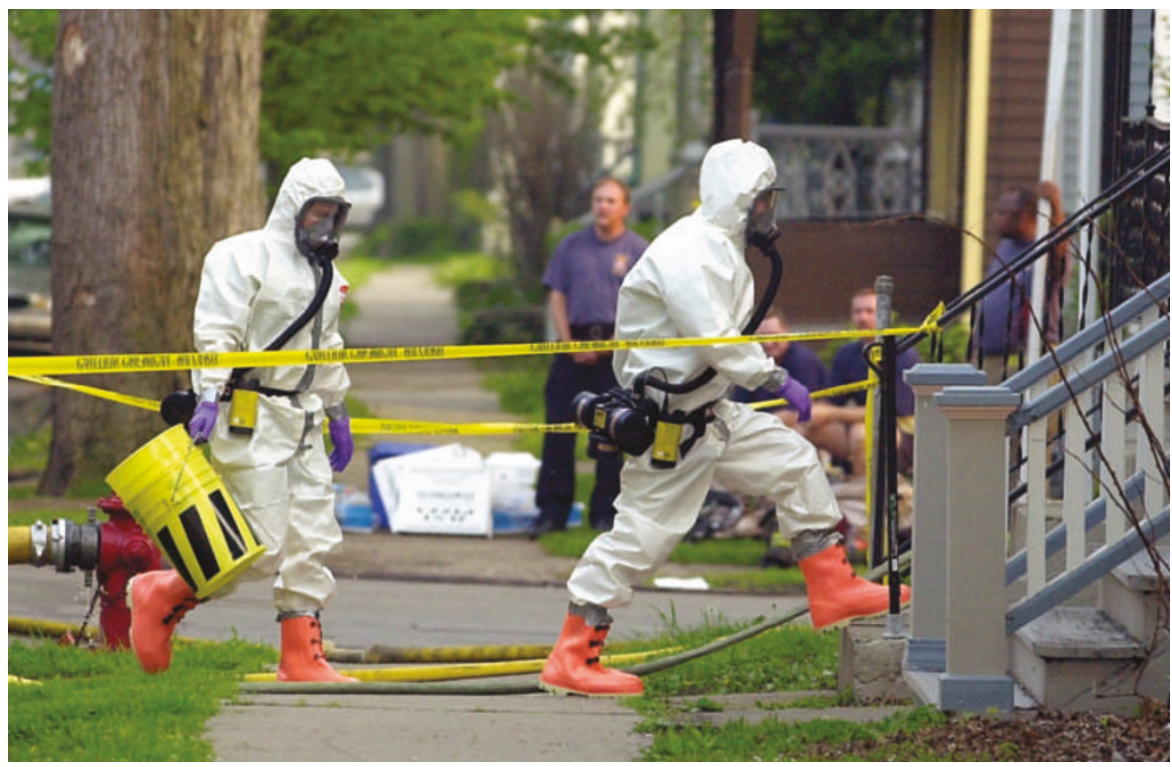

Taking the strain: agents took lab equipment from artist Steven Kurtz's home following his wife's death.

\title{
Bacteria raid may lead to trial for artist tackling biodefence
}

Geoff Brumfiel, Washington

An artist who uses live organisms and laboratory equipment in his performances is being scrutinized by federal officials who suspect he has broken bioweapons laws.

Federal prosecutors are deciding whether to file charges against Steven Kurtz, an art professor at the State University of New York at Buffalo, for possessing strains of bacteria, laboratory equipment, and several books on biowarfare. But Kurtz's friends and supporters say that the materials are part of his group's performance pieces.

Since 1987, 46-year-old Kurtz has been part of a Buffalo-based performance group, the Critical Art Ensemble, whose work offers political commentary on scientific topics. They often incorporate laboratory techniques into their shows, according to Nato Thompson, a curator at the Massachusetts Museum of Contemporary Art in Boston who has seen the group's work. "The lab experiment is the performance," he says.

The current investigation began with the death of Kurtz's wife, Hope, on 11 May. Medical staff responding to an emergency call from Kurtz noticed some "materials that made them uneasy" in his home, according to Paul Moskal, a spokesman for the Federal Bureau of Investigation. Officers from the bureau searched the house and questioned Kurtz about materials found there.

Moskal declined to comment on what the search uncovered, but Claire Pentecost, a photographer at the Art Institute of Chicago and long-time friend of Kurtz, says that investigators carried off samples of Bacillus globigii, Serratia marcescens and a benign form of Escherichia coli. They also seized laboratory equipment, including a polymerase chain reaction (PCR) machine and books on biowarfare, she says. The books were part of the group's latest project, The Marching Plague, which simulates an anthrax attack as part of its critique of government germwarfare research.

Analysis showed that the biological materials removed from the Kurtz home posed no threat, and an autopsy of Hope Kurtz revealed she had died of a heart attack. Authorities have nonetheless decided to bring a case against him before a grand jury; this will determine whether he can be prosecuted in court.

The US attorney's office in Buffalo declined to comment on the case, but a website that supports Kurtz's group says the case is being pursued under the Biological Weapons Anti-Terrorism Act of 1989. The act was amended under the USA Patriot Act of 2001 to allow the prosecution of "whoever knowingly possesses any biological agent, toxin, or delivery system".

Jonathan Turley, a lawyer at George Washington University in Washington DC, says that he thinks prosecutors are unjustified in pursuing criminal charges. Turley defended Texas Tech University plague researcher Thomas Butler in his recent federal trial (see Nature 426, 593; 2003). "The clear expectation of Congress was that the justice department would exercise a modicum of judgement," he says. "This law is designed to deal with the likes of al-Qaeda, not Andy Warhol."

Kurtz was due to appear before a grand jury in Buffalo on 15 June, when his supporters planned to rally in his defence. 